\title{
Popular Culture and Hegemony in Novel Everything Everything (A Discourse Analysis)
}

Wuriy Handayani ${ }^{1}$, Ninuk Lustyantie ${ }^{2}$, Zuriyanti ${ }^{3}$

${ }^{1}$ Perbanas Institute, Jakarta, Indonesia, 2,3Universitas Negeri Jakarta, Indonesia

E-mail: wuriyhandayani9906921001@mhs.unj.ac.id

Article Info
Article History
Received: $2021-11-02$
Revised: $2021-11-22$
Published: $2021-12-04$

Keywords: Pop Culture; Hygemony; Novel;

Discourse Analysis and Semiotics.

\begin{abstract}
Culture is the way people behave, socialize with others and using the language that he or she usually uses. Culture can change in so many ways. The way people talk, the way people wear dress and the way people use technology. The pop culture can be found in the story of Everything Everything by Nicola Yoon. It is reflected in the way the characters behave and the way the character has relationship with others. One of the certain facts, this novel has romantic story that like by people nowadays. This novel also shows as different culture from different world. Moreover, this novel shows the way teenagers behave in mienial era.The researcher in this novel try to find out some characteistics of popular culture and hegemony. This novel is analyzed using qualitative method. Discourse analysis used to analyze data in this novel. Parts of discourse analysis used are semiotic analysis by Roland Barthes and micro structure discourse analysis by Halliday. Based on the research, the writer find popular culture relates to American teenagers life. The writer also finds some hygemony such as freedom, marriage, family and domination of people who work in high position.
\end{abstract}

\begin{tabular}{l}
\hline Artikel Info \\
\hline Sejarah Artikel \\
Diterima: $2021-11-02$ \\
Direvisi: 2021-11-22 \\
Dipublikasi: 2021-12-04
\end{tabular}

Kata kunci:

Budaya Pop; Higemoni;

Novel;

Analisis Wacana;

Semiotika.

\begin{abstract}
Abstrak
Budaya adalah cara orang berperilaku, bersosialisasi dengan orang lain dan menggunakan bahasa yang biasa dia gunakan. Budaya dapat berubah dalam banyak hal. Cara orang berbicara, cara orang memakai pakaian, dan cara orang menggunakan teknologi. Budaya pop dapat ditemukan dalam cerita Everything Everything oleh Nicola Yoon. Hal ini tercermin dalam cara karakter berperilaku dan cara karakter memiliki hubungan dengan orang lain. Salah satu faktanya, novel ini memiliki kisah romantis yang disukai oleh orang-orang saat ini. Novel ini juga menunjukkan budaya yang berbeda dari dunia yang berbeda. Selain itu, novel ini menunjukkan bagaimana remaja berperilaku di era mienial. Peneliti dalam novel ini mencoba untuk mengetahui beberapa karakteristik budaya populer dan hegemoni. Novel ini dianalisis menggunakan metode kualitatif. Analisis wacana digunakan untuk menganalisis data dalam novel ini. Bagian analisis wacana yang digunakan adalah analisis semiotika oleh Roland Barthes dan analisis wacana struktur mikro oleh Halliday. Berdasarkan penelitian, penulis menemukan budaya populer berkaitan dengan kehidupan remaja Amerika. Penulis juga menemukan beberapa hygemoni seperti kebebasan, perkawinan, keluarga dan dominasi orang-orang yang bekerja di posisi tinggi.
\end{abstract}

\section{INTRODUCTION}

As an Indonesian citizen with various ethnicities and cultures, the term culture often appears in everyday life. Various forms of Indonesian cultural diversity are traditional houses, traditional ceremonies, traditional clothes, traditional dances, musical instruments, traditional weapons and special foods. In order for us to love Indonesian culture, we need to know the meaning of culture. Culture is a symbol of meaning that is regular and used in everyday life. This symbol will appear when someone expresses their feelings and makes judgments about something. Symbols will turn into meaning when humans communicate and develop their knowledge and symbols also control behavior
(Geertz 2013). From the quote above, we can see that culture is a symbol created by humans when they think and express their feelings. Culture arises because of curiosity and knowledge. Culture is also used to develop human life and control human behavior.

Culture can be the way humans behave, socialize with others, use the language they use, and their beliefs about something. Along with the times and technology these things can change. For example, changes in the behavior of someone who had worked together turned into an individual. Someone who used to socialize and communicate directly now communicates using social media. Someone who usually uses the local language or Indonesian has now changed to using 
slang. And a person's ideology or belief in something can change because of his knowledge and other views. So culture is always changing and will never be permanent.

These cultural developments and changes are studied in popular culture. According to Dominic Strinati (2016) in people with different groups and at different times have their own popular culture. Popular culture includes social processes and a collection of artifacts such as films, tapes, clothing, TV shows, and means of transportation and so on. Social processes in culture can be seen from who created the popular culture. Popular culture can be born from the common people themselves or born from high culture and high knowledge. Popular culture products are usually mass-produced and consumed by the general public.

One of the products of popular culture is literature. Literary works continue to develop in line with the development of the social environment that contains elements of trends and technology. The term literary works in popular culture is called popular literature. F.R Leavis and Denys Thompson quoted from (Storey 2010) blame popular literature for offering addictive forms of 'compensation' and 'distraction'. Moreover, they add, this form of compensation is both good and recreational in itself, for it tends-rather than reinforcing and invigorating the fondness for life, but increasing one's incompetence by accustoming him to humor that reflects weakness - to a refusal to face reality. The meaning of Leavis and Thompson's statement is that popular literature offers readers interesting things that make readers addicted. These interesting things add to the imagination of the reader. Often readers feel they are no longer in the real world but in the world of imagination that the author has built. Readers see the form of romanticism in literary works into a life that occurs in the real world. Leavis and Thompson feel that this is bad, because often readers can no longer return to the real world and fail to adjust to real life.

Furthermore, another characteristic of popular culture is the inclusion of other westernized cultures for example, the clothes used by teenagers in Indonesia. Clothing that uses a western model and does not cover the body in its proper place. Then the food eaten by Indonesians is no longer typical food but western food. Western lifestyle can occur because of colonialism in the past. In accordance with what Vyomakesisri, Sonu, and Srikanth (2019) said, popular culture is the root of the colonial era, colonialism exerts influence and encourages the emergence of this trend. This westernized trend is also seen in popular literature. There are many popular literary works that tell of freedom in association. Sex stories are no longer considered taboo but become things that must be presented because they sell. Stories about violence and crime are also considered interesting and selling. This is criticized by Hoggart (cited from Strinati 2016) new age arts such as sex and violence novels, obscene magazines, commercial pop songs and gramophones that make the working class lose themselves and their culture in "candy floss". thoughtless and trivial. The "glory" of brilliant barbarism, a world brought before them from across the Atlantic. According to him, popular literature is a threat to young people, young people will lose their identity and no longer think about the noble culture that carries norms and that exist in religion and life. They will be immersed in stories that prioritize physical violence rather than thinking logically.

In line with the development of popular culture, many popular literary works are produced by industry. Industry is starting to see things that people find interesting. The industry designs, produces and sells literary works that appeal to the masses. Popular culture is no longer formed by itself but is created by industry. As Morrell (2010) says, what is unique about mass production in pop culture is that culture is created, firstly, it is the desire of the industrial sector, and secondly, that mass industry must exist to design, produce, reproduce, selling the image of popular culture as a commodity. So most importantly mass production is created by the industrial segment. Literary works that are read by many people become a commodity. The literary work will be reproduced and become a best seller. The authors of the novels with the most sales get awards. A cultural expert, Adorno (quoted from Strinati 2016) tries to straighten out the differences between industrial ideas and mass culture. The concept of mass culture assumes that the masses have the same genuine responsibility for the culture they consume. So it is determined by the tendencies of the masses themselves.

Several studies on popular culture have been conducted before by several researchers. Among them FU (2015) tries to analyze popular literary works in China. He saw the link between language and popular culture reflected in a poem. Fu's research is only general in analyzing the 
relationship between popular culture and language without further analyzing the poem. The next research was conducted by Vyomakesisri, Sonu, and Srikanth (2019), they tried to find out the interaction and influence of popular culture on teenagers. They also try to reveal some of the popular culture that affects the lives of teenagers such as youtube, food, music, movies and cell phones. In this study, the researcher did not take one of the genres such as film or music to investigate further. The next research was conducted by Duff (2002), she links popular culture with the learning process. He tried to examine students' motivation when reading cyber texts which are a medium of popular culture. In contrast to previous studies, researchers tried to take elements of the narrative genre in the novel to examine more deeply about pop culture and the hegemony contained in it.

Regarding the novelty of this research, several researchers have studied the novel Everything Everytihing by Nicola Yoon. Among them is Lingkan Christita (2018) tries to find psychological factors that build Madeline's personality. The psychological theory he uses is Erik Erikson's psychological theory which contains the stages of personality before a person succeeds in getting what he wants. Furthermore, Aprilia (2019) tries to analyze the novel based on the study of feminism. The author sees Pauline's character as Madeline's mother who struggles to keep and care for Madeline. Then Rahayu and Wulan (2020) tried to examine the tenacity of the main character Madeline in revealing the truth regarding her illness. The last one is (Inaya 2021) who tries to find the form of anxiety that Madeline and her mother have. In contrast to previous research, this research has a newness in its study. The researcher tries to reveal the aspects of culture and hegemony in the novel by using discourse analysis

Nicola Yoon's Everythig Everything novel is a novel with a popular type of literature because it sells a romantic story between the main character named Madeline and the supporting character named Olly. The romantic relationship was in the shadow of Madeline and their intimate relationship. This romantic relationship continues in an unhealthy relationship that is not in accordance with existing norms. The relationship continued in casual sex which resulted in pregnancy. In addition to romantic relationships, some of Madeline's ways of life with other characters also show the lifestyle in the millennial era. Madeline and Olly use email and text messages from their mobile phones to communicate. Madeline was also given the freedom to use a credit card at the age of seventeen. Madeline does not go to school outside the home like teenagers in general, but she does school at home using the internet. In her life Madeline also likes the culture of other countries. Madeline who is from America loves French culture. Madeline often has dinner with her family using the French style of eating. In his writings the author uses sometimes different language for the sub-topic title of the novel everything-everything. Like the word menteuse which comes from Spanish which means thanking and piece de rejection which comes from French which means room for rejection. Furthermore, the word haiku comes from Japanese which means poetry. The novel Everything Everything was written in 2015 by Nicola Yoon, an American writer. Most of the readers of this novel are teenagers. The novel (Yoon 2015) became a New York Time best seller in 2017 and received several awards such as the Book Award for Young South in Carolina in 2018, the Evergreen Teen Book Award in 2018 and the Rhode Teen Book Award in 2017.

Nicola Yoon's novel Everything Everything not only displays popular culture at this time, but also displays the concept of hegemony. Hegemony is a culture produced by different social groups. The social groups have differences in social status and hierarchy. If social groups from the upper class use their power, then the lower class will experience oppression. Social groups from class will show their power because of interests such as ideological, political, economic and social interests. As Gramsci said (quoted from (Enrique and Ramirez 2015), hegemony is exercised by the ruling class not only through coercion, but also through consensus, managing to impose their worldview, against customary philosophies and 'common sense'. which supports the recognition of its dominance by the dominated classes. Strinati (2016) also adds about the interests of the upper class. According to him, the interest of the group is related to the economy. The upper class views the working class from the lower class as a low class who must be given wages. The top group also sees all from the side of wealth and profit.

The hegemony in the novel Everything Everything by Nicola Yoon is related to the hegemony built by the characters in the story. Among them are ideological hegemony, power 
hegemony between superiors and subordinates and hegemony in marriage. Madeline is a seventeen year old teenager. For seventeen years he was not allowed to leave the house by his mother. Madeline is always in her very hygienic room because of her immune disease. Madeline's mother was sure that the air and germs outside the house would slowly kill Madeline. Madeline's mother employed a nurse and the nurse's child at her home. Nurses always treat and give medicines. After Madeline's meeting with Olly, the ideology for living freely outside the home began to take shape. Madeline began to feel the desire to live freely like other teenagers. He wants to socialize with other people and breathe free air. The hegemony of the ideology of freedom dominated by Madeline's mother began to be violated. Hegemony is seen in the power of Madeline's mother who employs nurses and the children of the nurse. The nurse's daughter, Clara, was easily dismissed by Madeline's mother for helping Madeline meet Olly. Clara and her mother had worked at Madeline's house for years and they were already part of the family. However, because Madeline's mother felt more powerful and her interest in keeping her child in the house was violated, Madeline's mother showed her power. The hegemony of power is also seen in the life experienced by Olly's father. Olly's father who is a lower-class worker must be frustrated and angry because he was dismissed from work. The last is hegemony in marriage. Due to work pressures and the company's decision to quit his job, Olly's father often bullied Olly's mother, scolding and beating her.

To describe the study of popular culture and hegemony in the novel Everything Everything, the author will use discourse analysis studies. Jorgensen and Phillips (2007) mentioned that discourse analysis is a multidisipliner method, it can analyze many subjects in this world including literature. Besides Halliday and Hasan (quoted by Gleason and Ratner (1993) discourse is a linguistic unit consisting of text and context. Text is not only an element of written language but also spoken. In this case the text is linguistic units. It can be understood that the novel is a written text in the form of a narrative text. Narrative text usually tells the events at a certain time in sequence. Initial events and other events will be related to each other in the context built by the author of the story. The text in the novel is also complete in terms of language because there are words, sentences, clauses or phrases embedded in it.
The author will try to find symbols related to popular culture in the novel. Like previous research conducted by Vladimir Propp (quoted by Renkema 2004), Propp conducted a discourse analysis research on a fairy tale and found 31 functions such as injuries, obstacles, violations and others that were lived by the characters in the story. In this study, Propp did not link the function and character in the story. Propp just looking for the form of the fairy tale. In contrast to Roland Barthes who tried to find a relationship between the sign or sign with the signified or signified. Roland Barthes in (Strinati 2016) says that the signs of popular culture can be seen from the hidden meanings. With signs humans can express anything from human relationships with signs. For example, when someone gives roses, this can be a sign of a joke, joke, gratitude or affection. This study uses Roland Barthes' semiotic theory to reveal the content of texts that contain popular culture. Roland Barthes tried to find method that analyze narrative text such as novel and short story as a text itself that refers to problem in narrative story. There are five codes that he formulated, those codes are the hermeneutic code (HER) is used to examine confusing and puzzling elements that arise from the narrative and need to be explained, the semic code (SEM) is used to identify connotative expressions in the narrative. These help to build up the quality and depth of a character or an action, the symbolic code (SYM) is used to examine symbolic templates that are reflected in the basic binary oppositions located in the deep structure of the narrative, the proairetic code (ACT) is used to examine the verbs of the text categorizing them into semantic fields. The cultural code (REF) is used to examine details that refer to sociocultural context of the narrative and are connected to cultural authorities and communal thinking (Tohar et al. 2007).

Finding the concept of hegemony in the novel, the writer uses microstructure analysis in discourse. Microstructure is the meaning of discourse that can be observed by analyzing words, sentences, propositions, clauses and phrases. The microstructure according to Halliday and Hasan quoted by (Gleason and Ratner 1993), is divided into eight parts of cohesion those are reference, pronominal, demonstrative, comparative, substitution, conjunction, elepsis and lexical. Halliday and Hassan defined cohesion as referring to something which has been mentioned before. One type of cohesion is called reference. 
Reference is a semantic relation that refers to information mentioned in the text that needed interpretation. Pronoun often uses are she, he, it his her and their to refer to earlier items (Carroll 2008). When a character or a topic has been mentioned, speakers and writers can use pronoun as they continue to talk about it. Another form of cohesion is the use of demonstratives, meaning pronoun such as this/these, that/those, here/there. Then to talk a certain topic, people use comparatives, which refers to some contrast between present and previous objects. Rather than continually repeating themselves, speaker often use a variety of expressions to refer to the same thing which is called substitution. A particular from of cohesion is the use of various conjunctions, conjunctions to link sentences in discourse. Speakers and writers often delete grammatical parts of sentences that would be unessarily repetitive, a type of cohesion known as ellipsis. To create connections between sentences in a discourse, speakers use synonyms, its called lexical cohesion (Gleason and Ratner 1993).

This research is very necessary to examine the contents of the novel which are related to the forms of popular culture and the lifestyle of teenagers in America today. In addition, this research is very important to do to reveal the types of hegemony contained in the novel. This study focuses on the characteristics of popular culture and hegemony shown by the characters in the novel Everything Everything in living their daily lives. Researchers will describe how the representation of popular culture and hegemony with a discourse analysis approach.

\section{METHOD}

In this study, researchers used qualitative research. According to (Creswell 2018) a qualitative study is defined as an inquiry process of understanding a social or human problem, based on building a complex, holistic picture, formed with words, reporting detailed views of informants, and conducted in a natural setting used to describe data that cannot be counted. In other words, qualitative research is more descriptive in nature which is used to reveal in detail the data in the form of words or sentences. The data in this study is the novel Everything Everything written by Nicola Yoon (2015) with a total of 219 pages. Data collection techniques in this study include the selection of words, phrases, clauses or sentences related to popular culture and hegemony contained in the novel.
To uncover symbols related to popular culture, data analysis procedure in this study begins with grouping sentences into five codes of Roland Barthes, those codes are the hermeneutic code (HER), the semic code (SEM) the symbolic code (SYM), the proairetic code (ACT) and the cultural code (REF). Furthermore, to determine the presence or absence of hegemony in the novel, the writer analyzed words, phrases, clauses using Halliday and Hassan's eight parts of coherence. Those are reference, pronominal, demonstrative, comparative, substitution, conjunction, elepsis and lexical. Then the writer describes the results of the analysis and draw conclusions.

\section{RESULTS AND DISCUSSION}

The results are divided into two parts, namely symbols related to popular culture and hegemony in novel Everything Everything by Nicola Yoon. In this research, the writer found five kinds of symbol resemble popular culture, namely hermeneutic, semix, symbolic, proairetic and cultural code. Besides that, there are four kinds of hegemony; hegemony in family, hegemony in marriage, hegemony in domination of people who work in high position and hegemony of freedom.

A. Symbol of popular culture in novel Everything Everything

1) Hermeneutic code (HER)

Based on Roland Barthes hermeneutic code (HER), the writer tried to find whether the characters in the story asked any questions or expressed any uncertainty relate to pop culture. In the chapter titled First Contact, Part Three, Madeline as some questions to Olly about the way he looks. Why most of the time Olly uses cap, wear black cloth and has a tatoo in his right arm. Madeline asks those questions because she gets confused with the way Olly wear black all the time. She also needs an information about teenager culture nowadays, since most of her time she stays at home. Olly does not say much about it, he says that if he wears black cloth, he will look sexy. Olly's performance is the reflection of teenagers nowadays. They think if they wear hat, black cloth and tatoo, they will look more masculine. As it is mentioned by Strinati (2016) one of the example of popular culture is mass media that focused on big market consumers. Those consumers are very passive and easy to be exploited such as teenagers who like to buy 
dress, follow certain fashion syle, music and model. Let see the following dialogue:

Madeline: Since we're going to be friends, I have questions: Where are you from? Why do you wear a cap all the time? Is your head oddly shaped? Why do you only ever wear black? Related questions: Are you aware that clothing comes in other colours? I have suggestion if you need them. What do you do on the roof? What's the tatoo on your right arm?

Olly: I have answers: we're from all over, but mostly east cost, I shaved my head before we moved here (big mistake). Yes. I'm deadly sexy in black. Yes none needed, thanks, nothing. Barcode (page 36)

In the next chapter titled Menteuse, Madeline asks her mother what is the word "liar" in French. In here there is a puzzle between the question asked by Madeline and the word "menteuse" as the sub topic in this novel. The word "menteuse" means liar in French. Some of the words used by Madeline are a combination of English and other languages. Like the word "menteuse" which means to lie. The use of beaded language in a community group is one of the signs of popular culture. Because in accordance with the wishes of the general public, usually the most popular and widely used language by many people or teenagers at this time is the language that is considered original. This language can be brought from television media, movies or favorite songs. Like what was said by Moody (2012) pop culture use language varieties that are not native to either the performers or the audience. The varieties, however, in each of these cases may be considered "authentic" for the style or genre of the performance in example hip hop or rock music. Let see the following dialogue between Madeline and her mother.

"I've just been reading too much. You know how I get with a good book. I make my voice as reassuring as possible. I don't want her to worry. She has enough to worry about with me as it is.

"How do you say "liar" in French?" (Page 21)

2) Semix code (SEM)

Next is the semix code (SEM) which is used to identify connotative expression.
Most of the time characters in the story use connotative expressions relates to them believe, feeling and opinion about a group of artifack in popular culture such as television, film and clothes. As stated by Hebdige quoted by Strinati (2016), popular culture is a collection of artifacts which in general such as films, tapes, clothing, TV, means of transportation and so on. One of the artifacts that developed in popular culture is the internet. Today's young people can not be separated from the use of the internet. The internet is used as a means of communication and finding sources of information. As Madeline thinks about using the internet; According to her, the use of the internet does not only look at certain videos, such as fauna videos about cats but more than that. We can see in Madeline's speech below:

"Cat video," I say through mouthful of Turkey. Urgh, wrong thing to say. Carla lives for cat videos. She thinks they're the only thing the internet is good for." (Page 43)

Then there is a figurative sentence that Clara, one of Madeline's nurses, mentions. Clara gives an opinion about the lifestyle of today's teenagers. The lifestyle of teenagers who are given a little freedom but instead asks for more freedom. As stated by (Strinati 2016) in the development of popular culture, individuals in mass society are allowed to do as they please, the fewer communities or institutions that find the values of life. It is the same with teenagers who choose to get the freedom to do what they like without paying attention to the norms and values that exist in society. This can be seen in Clara's speech below:

"Teenagers are the same all over. Give them an inch and they'll take a mile."

"Is that a no?" I ask. (Page 45)

After that Madeline described a favorite room. The room is almost entirely made of glass. The decoration of the room was made to match the room in a tropical forest that she saw in the movie. There are trees, animals, streams of water and furniture that matches the forest. Based on Madeline's description of the room in her house, it is clear that the decoration of the room was taken from a movie she had watched. Films are various types of 
artifacts from popular culture. Through popular culture people will have ideas, knowledge and descriptions of everything that developed at that time (Vyomakesisri, Sonu, and Srikanth 2019). The development of ideas and descriptions of rooms in Madeline's house is the development of ideas from popular culture that she knows through films. This can be seen in the quote below:

The room's decor is like a movie set of tropical rain forest. It's filled with realistic and lush-looking fake tropical plants. Banana and coconut trees laden with fake fruit and hibiscus palnts with fake flowers are everywhere. There's even a babbling stream that snake its way through the room, but there are no fish-at least no real ones. The furniture is aged white wicker that looks like it's been sitting in the sun. Because it's mean to be tropical, my room keeps a heated fan running and a slightly too-warm brezee fills the room. (Page 52)

3) Symbolic code (SYM)

Symbolic codes explain hidden stories that are not revealed by the characters directly. The hidden stories or ideas are expressed in certain symbols related to popular culture (Tohar et al. 2007). Like when Madeline explained about her allwhite room. Madeline's books are also neatly wrapped and protected from germs. The white color and the hygienic books represent symbols of popular culture associated with high culture, a culture created by people with high knowledge. As asked by Strinati (2016) where does popular culture come from? Was he born to a commoner? Does popular culture emerge from the upper or lower classes or the interaction of the two. In this novel, the author describes Madeline as a teenager who is in an upper-class social status. Madeline is also very educated, she often reads books, watches movies and knows several languages. This can be seen in the following quote from the story:

In my white room, against my white walls, on my glistening white bookshelves, book spines provide the only color. The books are all brand-new hardcovers-no germy secondhand softcovers for me. They come to me outside, decontaminated and vacuum-sealed in plastic wrap. (Page 1 )

Next is bundt cake, Olly's family gave a cake to Madeline's family as a symbol of introduction. As also discussed by Roland Bathes in FU (2015), signs can be understood correctly if they are separated from the context in which they are used and interpreted. Like when someone gives roses, there must be a symbol of the gift. The symbol of introduction in this novel is giving a cake to show the social relationship between Olly's family and Madeline's family. This often happens in the community when there is a new neighbor who just lives near our house. Gifts can be in the form of cakes or other foods. So, this behavior can be associated with popular culture behavior, where people try to improve social relations or increase intimacy and closeness by giving something without any strings attached or paid. This can be seen in the dialogue below:

"My mom sent a Bundt." The voice is deep and smooth and definitely amused. My brain is processing the word bundt, trying to get an image of what it looks like before it dawns on me just who is at the door, Olly. (Page 22)

The next symbol that appears relates to the color of the shoes used by Madeline. Madeline always wears black shoes. In Olly's opinion, the black shoes made Madeline look sad and gloomy. From what Olly said about the meaning of black, the color is a symbol of sadness and gloom. Many people in the world believe that black is a color associated with sadness, so many people use this color at funerals. As stated by Vyomakesisri, Sonu, and Srikanth (2019), everyone has their own popular culture when it comes to entertainment such as movies or music and fashion. Likewise, with Olly and Madeline they both like black as their fashion. As discussed in the dialogue below:

\section{"And you complain about my wardrobe choices?" \\ "You only wear black! It makes you look sepulchral." (Page 68)}

4) Proarietic code (ACT)

Proarietic code according to Barthes relates to verbs in a story. The verb 
describes the activities carried out by the characters in the story. This activity is usually done by teenagers today and has become popular culture. In the novel Everything Everything, some of the activities that are often carried out by the characters in the story are related to the technology that is owned today. These activities include sending emails, reading messages via IMs and doing distance learning using the internet. In this novel, Madeline always communicates with Olly using email and short messages because Madeline's mother forbids her from meeting anyone other than her mother and nurse. Unlike other teenagers, Madeline is used to studying online through the internet at home. Madeline is also free to buy what she wants using a credit card. As Herbert Marcuse and (Storey 2010) say, popular culture is related to consumerism. The desire of people to be of certain types, to wear certain types of clothing, to eat certain types of food and to use certain technological goods that are not really needed. It's the same with Madeline and Olly who use the internet to communicate and use credit cards to buy things they don't really need. This can be seen in the email and the quotes below:

From: Madeline F. Whittier

To: genericuser033@gmail.com

Subject: hello

Sent: June 4, 8:03 PM

Hello, I guess we should start with introduction? My name is Madeline Whittier, but you can tell that from my email address. What's yours? (Page 34)

Olly: You mean you don't go to SF Valley High? Where do you go?

Madeline: I mean I don't go to regular school I go online. (Page 48)

\section{We've received your credit card application}

Thank you for applying for your new Argentis FreedomCard, the credit card that allows you the flexibility and spending power to pursue your dreams and plan for the future. (Page 82)
In addition to activities related to the use of technology, other activities carried out by the characters are activities that are not in accordance with the noble culture. Like smoking or having an inappropriate relationship while dating. In this story Madeline has an inappropriate relationship with Olly before marriage. Olly's sister also often does bad things such as drinking liquor and smoking. As Hoggart quoted by Strinati (2016) as saying, another characteristic of popular culture is the "brilliant barbarism" that is the degrading of working-class people, the abundance of novels that tell tales of lewd romances and the lives of teenagers in bars smoking and drinking. We can see it in the following quotes:

Times Olly's dad called kara a goddamn freak for wearing black nail polish.

Times Olly's dad mentioned that he kows someone has been drinking his goddamn whiskey

Cigarettes Kara buried in the garden this morning: (Page 74)

He pulls his T-shirt off over his head and my body takes over my brain. I run my fingertips over the smooth hand muscles of his chest, dip them into valleys between them. My lips follow the same path, testing, caressing .... (Page 155)

5) Cultural code (REF)

The cultural code describes the culture that exists in the story. In the novel Everything Everything there are several other cultures that are told such as French, Japanese and American cultures. One of the cultures mentioned by Madeline is Turkey Tuesday. Turkey Tuesday is a culture of giving food in the form of turkey meat and other foods to people in need in the context of Thanksgiving in America. Then Madeline and Olly went to Hawaii where they were given a lei or cultural composition as a tradition of receiving guests. Next, the tradition of eating like the French is told by Madeline. Madeline was used to having French-style meals with her mother. And Madeline often writes a poetry which is called Haiku by the Japanese.

Everything at Friday night dinner is French. The napkins are white cloth embroidered with fleur-de-lis at the 
edges. The cutlery is antique French ornate. We even have miniature silver to our la tour Eiffel salt and pepper shaker. (Page 21)

"Nothing." I take a bite of the sandwich. It's Turkey Tuesday. (Page 43)

His last letter is haiku. (Page 181)

"You, my dear, need a lei," he says. He nods at a greeter who hasn't yet found her party." (Page 135)

B. Hegemony in novel Everything Everything

As it is mentioned by Gramci quoted by Ives (2017) hegemony based on social class in economic structure. The upper-class people who own companies or land owners have a higher status than the lower-class people who earn wages. Those people often dominate the lower-class people.

1) Hegemony in family

Text 1

His dad is home from work and something's wrong because he's angry and getting angrier by the second. He grabs the Bundt cake from Kara and throws it hard at Olly, but Olly's too fast, too graceful. He dodges, and the cake falls to the ground. (Page 24)

From the first text above the word because does not have a comma until the end of the sentence, it means that Olly's father getting angry and angry again because something went wrong. The second sentence above, conjunction but is a rejection of the first clause. In the first clause it is said that Olly's father took a bunt cake from Kara and threw it at Olly, but in the second sentence Olly ran very fast and very gracefully to avoid throwing the cake. Then the third sentence uses conjunction and to explain that if Olly didn't look down, the cake would hit him.

Text 2

Madeline: What happened? Why was he so angry?

Olly: I don't know what you are talking about. (Page 38)

In the second text above, there is ellipsis reference, because at the beginning of the phrase the subject is omitted. Madeline omitted the subject at the beginning of the sentence because she thought Olly knew who the person she was talking about and they had the same perception.

Text 3

Times Olly's dad mentioned that he knows someone has been drinking his goddamn whiskey; that he's the smartest guy in the house; that no one should forget that he makes all the money. (Page 74)

In the third text above, there is pronominal reference. That in the sentence below refers to the subject mentioned before. It refers to Olly's father who is the smartest guy and the one who makes all money.

From the analysis above, we know that there is hegemony in the family since Olly's father is the person who is very dominant in the family. Olly's father is the person who earns money in his family and become the person who is afraid by the whole family. Olly's father often gets angry and hurt all the member in the family, they are Olly's mother, Olly's sister and Olly.

2) Hegemony in marriage

Text 4

But her defiance doesn't last. She takes a step toward him. He grabs at her, all anger and menace. But Olly's suddenly right there in between them. He swats his dad's arm away and pushes his mom off to the side (Page 96)

From the text four above, there is pronominal reference, ellipsis reference and conjunction reference. The pronominal reference is in the first sentence, she refers to her, who is Oll's mother. The ellipsis reference is in the second sentence, subject of the second clause is omitted. The phrase "All anger and manace" should be "all his anger and manace". Writer of this story omit the subject in the second clause, because he thinks readers know person who usually gets angry and menace, that person is Olly's father. The last sentence of text four is conjunction reference. Conjunction and in that sentence has function of narrator continuation; Olly tries to safe his mother by swipes his dad arm and pushes his mom away.

From the analysis above there is hegemony in Olly's parent's marriage. Olly's father is the most dominant person in his marriage. Olly's father often hurts his wife 
feeling and hits her body. She can not do anything and does not want to fight for her self. She receives all the painful and sorrow by her self until Olly stands up for her.

3) Hegemony in domination of people who work in high position.

Text 5

Eventually, though, his voice just turns to angry. "You are firing me? You just say those asholes were clearing me."

"I don't care about the goddamn money.

Don't do this, Phil. If you fire me everyone's going to think ...." (Page 78)

The situation in the text above, Olly's father received a call from the boss where he worked. His boss fires Olly's father. From the first sentence above there is a demonstrative reference. The word those is related to the sentence previously mentioned. The sentence is not mentioned in the dialogue above because it relates to the answer on the phone. Olly's father said the word those because it relates to people they already know and information about that person is not new. In the second sentence, Olly's father uses a future conditional sentence, namely "If you fire me everyone's going to think ..." Olly's father uses this sentence to show conditions that will really happen in the future. If Olly's father's boss still fires him, people will think that he did something that is not right. Because usually people who are fired or removed from work are people who make a mistake or do things that are detrimental to the company.

Text 6

"She turns back to Carla, "You are fired." "No, please, Mom. It wasn't her fault."

"Carla, pack your things and go." (Page 100)

Text 6 shows hegemony between Madeline's mother and Carla. Previously Madeline's mother was angry because Carla helped Madeline meet Olly, without the knowledge and permission of Madeline's mother, Carla brought Madeline and Olly meet each other. This angered Madeline's mother and even fired Carla. In the first sentence there is a pronominal reference. The word you refer to the previously mentioned Carla. While the word it refers to an incident that Madeline, Carla and her mother already knew.
From the analysis above, it can be concluded that Olly's father is a group of workers who are under pressure from superiors and the company where he works. Upper class groups such as bosses and companies can become more dominant by putting pressure on their employees and even firing them. Then, we know that Madeline's mother is Carla's boss who dominates Carla. Even though Carla has been working for a long time, Madeline's mother still fires Carla.

4) Hegemony in freedom

\section{Text 7}

“Besides, firing Carla, she's also revorked my internet privileges and canceled my in-person asrchitecture lesson with Mr. Waterman." (Page 105)

Text 7 describes the domination made by Madeline's mother over Madeline. After Madeline's mother found out that Madeline was friends and met Olly, Madeline's mother was angry and restricted all of Madeline's activities such as the internet and her meeting with people. In the sentence above there is a pronoun reference and a conjunction reference. The word she refers to the previous sentence, namely the person who fired Carla and the word and adds a description of what Madeline's mother is now limiting.

Text 8

"My mom catches up to me, her face is ruin of fear. "What are you doing? What are you doing? You have to get inside."

My vision tunnels and I hold her in my sights. "Why, mom? Why do I have to go inside?"

"Because you are sick. Bad things could happen to you out here." (Page 192)

Text 8 describes the desire of Mandeline's mother to keep Madeline in the house. Previously Madeline had proven that her mother had been lying by saying that Madeline had an immune disease. Since Madeline was proven healthy, she was free to go out of the house. In text 8 there is a pronominal reference, $\mathbf{W H}$ questions and a conjunction reference that can be analyzed. The word her refers to the previous sentence, namely Madeline's mother. Furthermore, Madeline's mother used the sentence WHquestions, because she needed a broader 
explanation than yes or no questions. The word what is used to ask Madeline for an explanation about Madeline intention to leave the house. Meanwhile, the word why was used by Madeline to ask the reason why her mother kept telling her to stay at home, because according to her, the reasons her mother always told her were no longer appropriate. Then the conjunction and in text 8 explains the continuation of the actions taken by Madeline. Madeline's thoughts and eyes focused solely on her mother after her mother said she had to stay home. Then the conjunction because shows the reason and persistence of Madeline's mother to keep Madeline in the house.

Based on the analysis of the text above, we know that Madeline's mother dominates Madeline's life and take's Madeline freedom. Madeline's mother does not allow Madeline to go out of the house, she is also not permitted to associate like other teenagers.

\section{CONCLUSSION AND SUGGESTION}

\section{A. Conclussion}

In conclusion there are some characteristic of pop culture found in novel titled Everything Everything by Nicola Yoon. First, pop culture relates to market consumer such as fashion style and model. Second, pop culture is brought by media like television, movie and music. Third, pop culture is artificial collection of technology such as internet, movie and television. Fourth, pop culture recounts new ideas, change teenager's behavior, and creates new cultural code. Moreover, there are some hegemony found in this novel, those are hegemony in Olly's family, marriage, domination of people who work in high position and freedom.

\section{B. Suggestion}

The writer hopes that the next researcher can explore more to find other charcteristics of pop culture and hegemony in this novel.

\section{REFERENCES}

Aprilia, Shella. 2019. "The Analysis of Pauline Through Feminism Theory on Everything, Everything Novel Writen by Nicola Yoon." : 1-56.

Carroll, David W. 2008. Psychology of Language. 5th ed. Thomson Higher Education.
Creswell, John W. 2018. Research Design Qualitative, Quantitative, and Mixed Methods Approaches. Fifth Edit. United States of America: SAGE Publications.

Duff, Patricia A. 2002. "Pop Culture and ESL Students: Intertextuality, Identity, and Participation in Classroom Discussions." Journal of Adolescent \& Adult Literacy 45(6): 482-87.

Enrique, Eugenio, and Cortes Ramirez. 2015. "CULTURAL HEGEMONY TODAY . FROM CULTURAL STUDIES TO CRITICAL PEDAGOGY Introduction: Why Cultural Hegemony Today? In the Course of Different Interpretations Throughout." 4: 116-39.

FU, Qilin. 2015. "The Signiflcances of Roland Barthes' Analysis of Popular Culture." Comparative Literature: East \& West 24(1): 63-65.

Geertz, Clifford. 2013. Anthropological Approaches to the Study of Religion Religion as a Cultural System.

Gleason, Jean Berko, and Nan Bernstein Ratner. 1993. Psycholinguistics. 2nd ed. United States of America: Harcourt Brace College Publishers.

Inaya, Maulida Khurin. 2021. "The Anxiety of Pauline and Madeline in Nicola Yoon'S Everything, Everything."

Ives, Peter. 2017. "Language and Hegemony in Gramsci." Language and Hegemony in Gramsci.

Jorgensen, Marianne W, and Louise J Phillips. 2007. "Analisis Wacana: Teori Dan Metode." Yogyakarta: Pustaka Pelajar.

Lingkan Christita, Shienna. 2018. "Proceedings 'English Language and Literature: Their Contemporary Roles."' In Yogyakarta: Faculty of Letters Universitas Sanata Darma, 87.

Moody, Andrew. 2012. "Language Ideology in the Discourse of Popular Culture." The Encyclopedia of Applied Linguistics (2010): 2007-9.

Morrell, Ernest. 2010. "Howard a Critical Pedagogy Popular Culture: Literacy 
Development among Urban Youth." 46(1): 72-77.

Rahayu, Siska Dewi, and Sri Wulan. 2020. "Resistance for Truth in Nicola Yoon'S Novel Everything, Everything." Journal of Language 1(2): 78-88.

Renkema, Jan. 2004. Introduction to Discourse Studies. Philadelphia, USA: John Benjamins North America.

Storey, John. 2010. Cultural Studies Dan Kajian Budaya Pop. IV. ed. Layli Rahmawati. Yogyakarta: JALASUTRA.

Strinati, Dominic. 2016. Popular Culture Pengantar Menuju Teori Budaya Populer. ed. St Sunardi. Yogyakarta: Narasi.

Tohar, Vered, Merav Asaf, Anat Kainan, and Rakefet Shahar. 2007. "An Alternative Approach for Personal Narrative Interpretation: The Semiotics of Roland Barthes." International Journal of Qualitative Methods 6(3): 57-70.

Vyomakesisri, Tippabhotla, Thigulla Sonu, and Doballi Srikanth. 2019. "POP Culture: Interaction of and Influence on the Youth." International Journal of English Literature and Social Sciences 5(1): 8-12.

Yoon, Nicola. 2015. Everything Everything. Great Britain: Penguin Random House UK.

Aprilia, Shella. 2019. "The Analysis of Pauline Through Feminism Theory on Everything, Everything Novel Writen by Nicola Yoon." : $1-56$.

Carroll, David W. 2008. Psychology of Language. 5th ed. Thomson Higher Education.

Creswell, John W. 2018. Research Design Qualitative, Quantitative, and Mixed Methods Approaches. Fifth Edit. United States of America: SAGE Publications.

Duff, Patricia A. 2002. "Pop Culture and ESL Students: Intertextuality, Identity, and Participation in Classroom Discussions." Journal of Adolescent \& Adult Literacy 45(6): 482-87.

Enrique, Eugenio, and Cortes Ramirez. 2015. "CULTURAL HEGEMONY TODAY . FROM CULTURAL STUDIES TO CRITICAL
PEDAGOGY Introduction: Why Cultural Hegemony Today? In the Course of Different Interpretations Throughout." 4: 116-39.

FU, Qilin. 2015. "The Signiflcances of Roland Barthes' Analysis of Popular Culture." Comparative Literature: East \& West 24(1): 63-65.

Geertz, Clifford. 2013. Anthropological Approaches to the Study of Religion Religion as a Cultural System.

Gleason, Jean Berko, and Nan Bernstein Ratner. 1993. Psycholinguistics. 2nd ed. United States of America: Harcourt Brace College Publishers.

Inaya, Maulida Khurin. 2021. "The Anxiety of Pauline and Madeline in Nicola Yoon'S Everything, Everything."

Ives, Peter. 2017. "Language and Hegemony in Gramsci." Language and Hegemony in Gramsci.

Jorgensen, Marianne W, and Louise J Phillips. 2007. "Analisis Wacana: Teori Dan Metode." Yogyakarta: Pustaka Pelajar.

Lingkan Christita, Shienna. 2018. "Proceedings 'English Language and Literature: Their Contemporary Roles.'” In Yogyakarta: Faculty of Letters Universitas Sanata Darma, 87.

Moody, Andrew. 2012. "Language Ideology in the Discourse of Popular Culture." The Encyclopedia of Applied Linguistics (2010): 2007-9.

Morrell, Ernest. 2010. "Howard a Critical Pedagogy Popular Culture: Literacy Development among Urban Youth." 46(1): 72-77.

Rahayu, Siska Dewi, and Sri Wulan. 2020. "Resistance for Truth in Nicola Yoon'S Novel Everything, Everything." Journal of Language 1(2): 78-88.

Renkema, Jan. 2004. Introduction to Discourse Studies. Philadelphia, USA: John Benjamins North America.

Storey, John. 2010. Cultural Studies Dan Kajian Budaya Pop. IV. ed. Layli Rahmawati. 
Yogyakarta: JALASUTRA.

Strinati, Dominic. 2016. Popular Culture Pengantar Menuju Teori Budaya Populer. ed. St Sunardi. Yogyakarta: Narasi.

Tohar, Vered, Merav Asaf, Anat Kainan, and Rakefet Shahar. 2007. "An Alternative Approach for Personal Narrative Interpretation: The Semiotics of Roland Barthes." International Journal of Qualitative Methods 6(3): 57-70.
Vyomakesisri, Tippabhotla, Thigulla Sonu, and Doballi Srikanth. 2019. "POP Culture: Interaction of and Influence on the Youth." International Journal of English Literature and Social Sciences 5(1): 8-12.

Yoon, Nicola. 2015. Everything Everything. Great Britain: Penguin Random House UK. 